Scientific journal

PHYSICAL AND MATHEMATICAL EDUCATION

Has been issued since 2013.

Науковий журнал

ФІЗИКО-МАТЕМАТИЧНА ОСВІТА

Видається з 2013.
ISSN 2413-158X (online)

ISSN 2413-1571 (print)

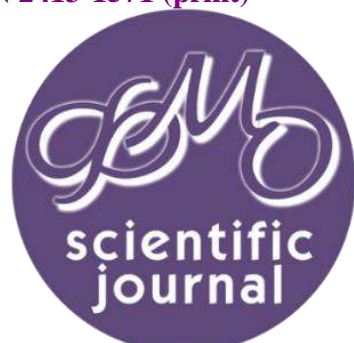

Базурін В. Методика навчання студентів роботи у середовищі EDraw Мах. Фізико-математична освіта. 2020. Випуск 2(24). С. 13-16.

Bazurin V. A method of studying students work in the EDraw Max environment. Physical and Mathematical Education. 2020. Issue 2(24). P. 13-16.

DOI 10.31110/2413-1571-2020-024-2-002

UDC 378.004

Vitalii Bazurin Olexander Dovzhenko Hlukhiv National Pedagogical University, Ukraine vbazurin@gmail.com ORCID: 0000-0002-6614-4889

\title{
A METHOD OF STUDYING STUDENTS WORK IN THE EDRAW MAX ENVIRONMENT
}

ABSTRACT

The article describes the components of the methodical system of teaching students to work in the EDraw Max environment. EDraw Max Graphics Editor is one of the best tools for building a home plan and designing engineering communications. In the process of studying EDraw Max graphic editor, student-builders develop such competence as the ability to solve professionally-important tasks using ICT tools. The article describes the requirements for students who start studying EDraw Max, used methods and means of training, types of training exercises, topics of laboratory work.

Formulation of the problem. The rapid development of information and communication technologies has led to the fact that they are included in many spheres of professional human activities, including construction. It is difficult to imagine the design of modern buildings and structures without the use of computer graphics.

The state standard of the specialty "Construction and Civil Engineering" defines one of the professional competencies "the ability to use modern means of computer technology for the solution of applied problems".

Materials and methods. State standard analysis, curriculum analysis, graphical editor functionality analysis, synthesis, generalization and systematization.

Results. The proposed topic of work was tested during 2017-2018 in the process of training students of specialty 015.01 "Vocational education. Construction". Learning outcomes are positive. Students completed most of the laboratory work. The use of EDraw Max was more effective than AutoDesk AutoCad.

Conclusions. The use of the EDraw Max graphic editor in the course of "Information and Communication Technologies" is fully justified.

KEY WORDS: computer graphics, vocational education, construction, EDraw Max.

\section{INTRODUCTION}

The rapid development of information and communication technologies has led to the fact that they are included in many spheres of professional human activities, including construction. It is difficult to imagine the design of modern buildings and structures without the use of computer graphics.

The state standard of the specialty "Construction and Civil Engineering" defines one of the professional competencies "the ability to use modern means of computer technology for the solution of applied problems" (Educational and professional program "Construction and civil engineering" of the first level of higher education in specialty 192 "Construction and civil engineering", 2016).

The professional activity of the construction engineer includes the development of work drawings, the construction of floor plans and other activities related to computer graphics. Building a floor plan, a house plan is an important component of a home design. Planning a floor plan, a home plan is done using the following software tools: Autodesk AutoCAD, Compas, Microsoft Visio, and others. However, according to the criterion of "efficiency - labor intensity", it is optimal to use the MS Visio graphical editor. This editor contains a set of ready-made symbols for the main components of the house plan. We will consider its free analogue - EDraw Graphic Editor.

Work with any software begins with familiarity with the its interface. However, this question often goes beyond the attention of methodologists. Graphic editors have a specific interface. Therefore, familiarity with the interface of EDraw graphics editor is an important step in the study of this software.

The method of studying the EDraw graphics editor largely depends on the functional features of EDraw and is currently not developed enough. 
Analysis of relevant research. The problem of teaching students the basics of computer graphics has been reflected in the findings of G. Taxen, D.G.Balreira, M. Walter and D.W. Fellner, N.A.Dodgson, and A. Chalmers, B. Bürgisser, D. Steiner, and R.Pajarola and other scholars.

G. Taxen proposes the elements of constructivist pedagogy to solve the problem of teaching computer graphics of university students. The article deals with the main computer-oriented means of computer graphics training. The author developed the 3D Graphics for Dummies training course. As a result of the course students acquired the skills of creating 3D models of solids, their animation and transformation. The effectiveness of this course was proved by experiment (Taxen, 2004).

D.G. Balreira, M. Walter and D.W. Fellner studied the content of computer graphics courses at universities of different countries. The authors singled out 24 main themes that should be studied in the course of computer graphics (Balreira, \&\& Walter\&\& Fellner, 2017).

N.A.Dodgson, and A. Chalmers (2017) disclose the construction of a one-year "Introduction to Computer Graphics" course for students at the University of Victoria in Wellington, New Zealand. The course developed by them consists of 34 lectures and 121 laboratory work. Introduction to computer graphics is integrated into a three-year computer graphics course. In the process of studying this course, students study the basic issues of computer graphics, visual tools for working with computer graphics and programming computer graphics (Dodgson \&\& Chalmers, 2017).

B. Bürgisser, D. Steiner and R. Pajarola give examples of application of frameworks glGAb FUSEE. The authors propose to perform 1 exercise per week ( 6 exercises only). These exercises cover the main topics of the Computer Graphics course and require the creation of appropriate computer programs. Student projects include creating scenes for computer games (Bürgisser, \&\&Steiner \&\&Pajarola, 2017).

E. F. Anderson has developed a course in computer graphics programming. C++ programming language is used for programming. The course ends with an exam and coursework. In the process of programming computer graphics students use the API (Anderson, 2017).

F. Liarokapis offers his approach to learning computer graphics. The scientist uses the means of Augmented reality. The author discovers the features of the study of the "Augmented Reality Interfaces" course: requirements, teaching methods, learning scenarios. Students study the following main topics: ray propagation, 3D object transformation, Bezier curves, Fundamentals of Computer Graphics, Texture Mapping, Image Effects. Students use Qt framework, ARToolKit and FBX SDK to program computer graphics. The article presents the results of a 2-year experiment (Liarokapis, 2017).

The aim of the article. However, these findings focus on developing students' skills to program computer graphics rather than studying graphic editors.

\section{RESEARCH METHODS}

State standard analysis, curriculum analysis, graphical editor functionality analysis, synthesis, generalization and systematization.

\section{RESULTS}

Methodology of Studying the EDraw Environment

Formed competencies

In the process of studying EDraw graphics editor by students, they develop the following competencies:

- the ability to rational thinking;

- the ability to use computer graphics tools to build floor plans (at home);

- the ability to plan their actions;

- the ability to design a plan of a building (floor).

The Short Characteristics of Graphic Editor EDraw

EDraw belongs to computer graphics tools. The software is licensed. Functional features of the software:

- construction of different types of schemes and diagrams that can be used in related fields of professional activity;

- construction of the plan of the house (floor);

- execution of basic operations with files (creation, saving, editing, printing);

- image conversion to PDF format (www.edrawsoft.com).

Requirements for students who are beginning to study EDraw

Getting to study EDraw, the student must have the following knowledge, skills and abilities:

- have an idea of the main elements of the file system;

- have skills in working with files and directories in MS Windows operating system;

- know the features of the interface of Windows-programs;

- to know the differences between the main types of computer graphics (raster, vector, fractal);

- know the main types of graphic files;

- be able to perform basic operations with files and directories in the graphics editor MS Paint (MS Paint.NET);

- be able to perform basic operations with the image and parts of the image in the environment of the graphic editor;

- know the notation on the plans of the houses.

\section{Methods of training}

In the process of studying the EDraw graphics editor, the following methods are used: the method of expedient examples; explaining the destination and key features of the EDraw graphics editor; demonstration of work methods in EDraw environment; method of training exercises.

\section{Means of training}

In the process of studying EDraw graphics editor, the following basic training tools are used:

- computer with installed operating system;

- EDraw Graphic Editor. 
In the process of studying EDraw, the following auxiliary learning tools are used:

- examples of floor plans;

- presentations;

- instructions for laboratory work;

- instructions for performing independent exercises.

\section{Exercises}

In the process of studying the EDraw graphics editor, the following types of exercises are used:

- performing basic operations with files and folders (creating, saving, renaming);

- construction of graphic images using primitives (lines and points);

- modification of created images from graphic primitives;

- modification of ready-made symbols (rotation, resizing, zooming);

- creation of floor plans using ready-made symbols;

- building a room plan;

- construction of a floor plan (at home);

- construction of the plan of the house with the adjoining territory.

All these types of exercises are implemented in the form of instructions for laboratory work on discipline "Information and communication technologies" for students of the specialty 015.01 "Vocational education. Construction".

\section{The Topics of Laboratory Work}

In the process of studying EDraw, the following laboratory work are applied:

1. Introduction to the interface and toolbar EDraw Max.

2. Construction of images using graphic primitives.

3. Construction of the plan of a private home using ready-made symbols.

4. Construction of a floor plan of a multistory building according to the model.

5. Design and construction of a floor plan of a multistory building.

6. Construction of a floor plan with the designation of water supply and sewage systems.

7. Construction of axonometry of water supply and sewage systems.

8. Construction of the master plan of the house with the adjoining territory.

Proposed topic of work was tested during 2017-2018 in the process of training students of specialty 015.01 "Vocational education. Construction". Learning outcomes are positive. Students completed most of the laboratory work. The use of EDraw Max was more effective than AutoDesk AutoCad.

\section{CONCLUSIONS}

The use of the EDraw Max graphic editor in the course of "Information and Communication Technologies" is fully justified. Students must have a certain initial level of knowledge and skills in computer technology in order for the training to be successful. Another important condition is the combination of a methodical system of methods, means and content of training.

In the future, we plan to develop a textbook and a collection of laboratory work "Computer Graphics in the EDraw environment" and determine its effectiveness by experiment.

\section{References}

1. Educational and professional program "Construction and civil engineering" of the first level of higher education in specialty 192 "Construction and civil engineering" of the field of knowledge 19 "Architecture and construction". Qualification Bachelor (2016) Ternopil. $17 \mathrm{p}$.

2. Taxen, G. (2004) Teaching computer graphics constructively. Comuter\&Graphics, San Diego, California - July 27 - 31, 2003 , Vol.28, Issue 3, p393-399. https://www.sciencedirect.com/science/article/pii/S0097849304000329 Last accessed: 2019/01/31.

3. Balreira, D. G., \&\&Walter, M., \&\&Fellner, D. W. (2017) What we are teaching in Introduction to Computer Graphics. The Eurographics Association, p.1-7. https://diglib.eg.org/handle/10.2312/eged20171019 Last accessed: 2019/01/31.

4. Dodgson, N.A.,\&\& Chalmers, A. (2017) Designing a Computer Graphics Course for First Year Undergraduates. The Eurographics Association, 2017, p. 9-15. https://diglib.eg.org/bitstream/handle/10.2312/eged20171020/009-015.pdf Last accessed: 2019/01/31.

5. Bürgisser, B., \&\&Steiner, D., \&\& Pajarola, R. (2017) bRenderer: A Flexible Basis for a Modern Computer Graphics Curriculum. The Eurographics Association, p. 27-34. https://diglib.eg.org/bitstream/handle/10.2312/eged20171023/027-034.pdf Last accessed: 2019/01/31.

6. Anderson, E.F. (2017) Generating ASCll-Art: A Nifty Assignment from a Computer Graphics Programming Course. In The Eurographics Association, p.17-18. https://diglib.eg.org/bitstream/handle/10.2312/eged20171021/017-018.pdf Last accessed: 2019/01/31.

7. Liarokapis, F. (2017) Using Activity Led Learning for Teaching Computer Graphics Principles Through Augmented Reality. In The Eurographics Association, p.43-50. https://diglib.eg.org/bitstream/handle/10.2312/eged20171025/043-050.pdf Last accessed: 2019/01/31.

8. Free download EDraw Max Pro. https://www.edrawsoft.com/ru/download-edrawmax.php Last accessed: 2019/01/31. 


\section{МЕТОДИКА НАВЧАННЯ СТУДЕНТІВ РОБОТИ У СЕРЕДОВИЩІ EDRAW MAX}

Базурін Віталій

Глухівський національний педагогічний університет імені Олександра Довженка, Україна

Анотація. У статті описуються компоненти методичної системи навчання студентів прийомам роботи у середовищі ЕDraw Мах. Графрічний редактор EDraw Мах є одним із оптимальних засобів для побудови плану будинку і накреслення інженерних комунікацій. У процесі вивчення графічного редактора EDraw Max у студентів-будівельників формується така компетентність, як здатність вирішувати професійно-важливі завдання з використанням засобів IKT. У статті розкрито вимоги до студентів, які починають вивчення EDraw Max, використовувані методи і засоби навчання, види навчальних вправ, тематику лабораторних робіт.

Формулювання проблеми. Стрімкий розвиток інформаційно-комунікаційних технологій призвів до того, що вони увійшли до багатьох сфер професійної діяльності людини, у тому числі й будівництво. Важко уявити проектування сучасних будівель і споруд без використання засобів комп'ютерної графіки.

Державний стандарт спеціальності «Будівництво та цивільна інженерія» визначає однією з фахових компетентностей «здатність застосовувати сучасні засоби комп'ютерної техніки для розв'язання прикладних задач».

Матеріали і методи. Аналіз державного стандарту, аналіз навчальних програм, аналіз функціональних можливостей графічного редактора, синтез, узагальнення і систематизація.

Результати. Пропоновану тематику робіт було апробовано протягом 2017-2018 років у процесі навчання студентів спеціальності 015.01 «Професійна освіта. Будівництво». Результати навчання позитивні. Студенти виконали більшість лабораторних робіт. Застосування EDraw Max виявилося більш ерективним, ніж AutoDesk AutoCad.

Висновки. Застосування графічного редактора EDraw Maх у курсі «Інформаційно-комунікаційні технології» є цілком виправданим. Ключові слова: комп'ютерна графіка, професійна освіта, будівництво, EDraw Maх. 